\title{
Ramularia areola sporulation potential in Brazilian cotton
}

\author{
Rafael Galbieri ${ }^{*}$, Edivaldo $\mathrm{Cia}^{2}$, Camilo de Lelis Morello ${ }^{3}$, Sheila Fanan ${ }^{1}$, Edson Ricardo de Andrade Junior ${ }^{1 *}$, Leimi Kobayasti ${ }^{4}$
}

${ }^{1}$ Instituto Mato-grossense do Algodão-IMA, BR 70, Km 266, Primavera do Leste, C.P. 149, MT.*Doutorando em Agricultura Tropical, FAMEVZ/ UFMT. ${ }^{2}$ Instituto Agronômico (IAC), bolsista do CNPq, Av. Barão de Itapura, 1481, Campinas, SP. ${ }^{3}$ Embrapa Algodão/Núcleo do Cerrado, Santo Antônio de Goiás, GO. ${ }^{4}$ Universidade Federal de Mato Grosso, campus Cuiabá, MT.

Autor para correspondência: Edivaldo Cia (cia@iac.sp.gov.br)

Data de chegada: 22/05/2014. Aceito para publicação em: 09/06/2015.

$10.1590 / 0100-5405 / 2008$

\begin{abstract}
Galbieri, R.; Cia, E.; Morello, C.L.; Fanan, S.; Andrade Junior, E.R.; Kobayasti, L. Ramularia areola sporulation potential in Brazilian cotton Summa Phytopathologica, v.41, n.3, p.233-235, 2015.

Ramularia blight, caused by Ramularia areola, is one of the most important diseases affecting cotton crop in Brazil. For its effective control, 5-9 fungicide applications on susceptible cultivars are necessary. The aim of the present study was to evaluate, in vitro and in vivo, the sporulation potential of $R$. areola isolates from different Brazilian regions at distinct temperatures. Spore production was assessed in the laboratory and under green house conditions by using leaves from plants of eight cotton cultivars. The in vitro results indicated that the potential of spore production was dependent on temperature. Maximum sporulation of the

fungus occurred at $17^{\circ} \mathrm{C}$ for isolates from São Paulo State and $23^{\circ} \mathrm{C}$ for isolates from Goiás and Mato Grosso States. In the in vivo study, there was a variation in spore production according to the cultivar and the isolate. Most isolates showed to be highly aggressive on cultivars FM966 LL and DELTAOPAL. The obtained results suggest a more rational use of fungicides and cultivars with decreased fungal sporulation and can form the basis for further studies of the pathogenic variability of this fungus in cotton crops in Brazil. This is the first report on the sporulation potential of Brazilian R. areola isolates.
\end{abstract}

Additional keywords: Ramularia blight, Gossypium hirsutum.

\section{RESUMO}

Galbieri, R.; Cia, E.; Morello, C.L.; Fanan, S.; Andrade Junior, E.R.; Kobayasti, L. Potencial de esporulação de Ramularia areola em algodoeiro no Brasil. Summa Phytopathologica, v.41, n.3, p.233-235, 2015.

A mancha de ramulária causada por Ramularia areola é uma das mais importantes doenças para a cultura do algodoeiro no Brasil. Para o controle efetivo da doença, são necessárias 5-9 aplicações de fungicidas em cultivares suscetíveis. O objetivo do presente trabalho foi avaliar, in vitro e in vivo, o potencial de esporulação de isolados de $R$. areola, originários de diferentes regiões do Brasil, sob diferentes regimes de temperaturas. A produção de esporos foi avaliada em laboratório e em folhas de plantas de oito cultivares de algodoeiro em condições de casa-de-vegetação. Os resultados obtidos in vitro indicaram que o potencial de produção de esporos foi dependente da temperatura.
A máxima esporulação do fungo ocorreu com $17^{\circ} \mathrm{C}$ para isolados originários do Estado de São Paulo e $23^{\circ} \mathrm{C}$ para isolados de Goiás e Mato Grosso. No estudo in vivo, houve variação na esporulação em função da cultivar e do isolado. A maioria dos isolados apresentou alta agressividade na cultivar FM 966 LL e DELTAOPAL. Com os resultados obtidos, é possível indicar uso mais racional de fungicidas, cultivares que apresentaram menor esporulação do fungo, além de formar base para novos estudos com relação à variabilidade desse fungo em algodoeiro no Brasil. Esse é o primeiro relato sobre o potencial de esporulação de isolados brasileiros de $R$. areola.

Palavras-chave: Mancha de ramulária, Gossypium hirsutum

Ramularia leaf blight in cotton, also known as false mildew, is caused by Ramularia areola (7) and is an economically important disease in Brazil, especially in the Center-Western Region of the country $(1,4)$. Highly favorable environmental conditions to the pathogen, as well as the use of susceptible cultivars, have made it potentially damaging in the absence of effective control measures $(1,2,5)$.

The initial symptoms of this disease are characterized by small angular necrotic lesions of 3-4 cm. In the infection advanced stages, the lesions coalesce and become necrotic with severe chlorosis, causing the premature death of leaves and affecting the production $(7,5)$. In the Brazilian Center-Western Region, yield losses caused by this disease are estimated to be around $20-30 \%$ when control measures are not adopted (1), but losses can reach up to $60 \%$, especially for highly susceptible cultivars (2). In countries like India, yield losses of over $60 \%$ have been recorded (8).

At present, this disease has been partially controlled in Brazil by 5 to 9 fungicide applications, which has increased the production cost (1). Although some resistant cultivars are available for commercial cultivation, their resistance has not been stable, and the disease response is variable in different Brazilian regions (3). The epidemiology of this disease is directly influenced by the pathogen's sporulation and dissemination capacity (5), and such processes depend on the interaction between the fungal genetic factors and the cotton plant, as well as on environmental conditions such as temperature $(7,5)$. Thus, it is important to study the variability of this fungus under different aspects in order to better understand what happens to this path system 
in Brazil.

The aim of the present investigation was to identify, in vitro and in vivo, the spore production potential of $R$. areola isolates originated from some endemic areas in Brazil.

First, ten $R$. areola monosporic isolates were collected from diseased cotton leaves at three different Brazilian States (São Paulo, Mato Grosso and Goiás), and the pathogen was cultivated on V8-juice agar. Then, to assess the fungal spore production, a trial was carried out on Petri platesat different temperatures and $12 \mathrm{~h}$ photoperiod in growth chambers $\left(12,17,21,23,26,29\right.$ and $\left.33^{\circ} \mathrm{C}\right)$. Each treatment was replicated eight times at random, totaling 560 plates. Suspensions $\left(10^{6}\right.$ conidia/mL) were prepared individually for each isolate bydispersing $1 \mathrm{~mL}$ in V8 culture medium (7) on each plate. The suspension was homogeneously spread throug hout the plate surface by using a Drigalski spatula; the incubations were conducted according to the assigned treatment. Ten days later, $40 \mathrm{~mL}$ of distilled water were added to each plate and the surfaces were scraped with a no. 14 brush to release the conidia. A subsequent spore count was carried out by using a Neubauer chamber and an optical microscope. A drop of Tween 20 was added to each plate to facilitate the procedure.

A second trial was carried out under controlled conditions in the greenhouse, where the temperature was kept at about $25 \pm \mathbf{2}{ }^{\circ} \mathbf{C}$. The experimental design was in randomized blocks, $8 \times 11$ factorial design, totaling eight cultivars and eleven $R$. areola isolates with four replicates. Experimental plots consisted of $12-\mathrm{L}$ pots with four plants. Isolates were: No.308 from Luiz Eduardo Magalhães-BA; 309 from BarreirasBA; 294 from Primavera do Leste-MT; 282 from Campo Verde-MT; 293 from Primavera do Leste-MT; 283 from Sorriso-MT; 281 from Lucas do Rio Verde-MT; 300 from Londrina-PR; 290 from MococaSP; 285 from Adamantina-SP; and 289 from Caiabu-SP. The inoculum was prepared as described for the first trial. Plants were inoculated at 60 days after planting by using a backpack sprayer until runoff.After twenty days, the spores on a third true leaf of each plant were counted. The spores on the upper and the lower leaf surfaces were scraped with a no. 16 brush and $80 \mathrm{~mL}$ distilled water. Spore counts were carried out in the resulting suspension by using a Neubauer chamber and an optical microscope. The average spore count of the four plants from each experimental plot represented the variable that was considered for analysis. Spore counts were subjected to analysis of variance and Tukey's test at $5 \%$ probability using the transformation $\sqrt{x+1}$.

Figure 1 shows the in vitro effect of temperature on $R$. areola sporulation. Considering the extreme temperatures studied, fungal sporulation was minimal at $12{ }^{\circ} \mathrm{C}$ and there was not any sporulation at $33{ }^{\circ} \mathrm{C}$. It can be assumed that the optimal temperature range for the event to occur is very close to the presented values, which corroborates the results obtained by Rathaiah (7). It is interesting to note that the

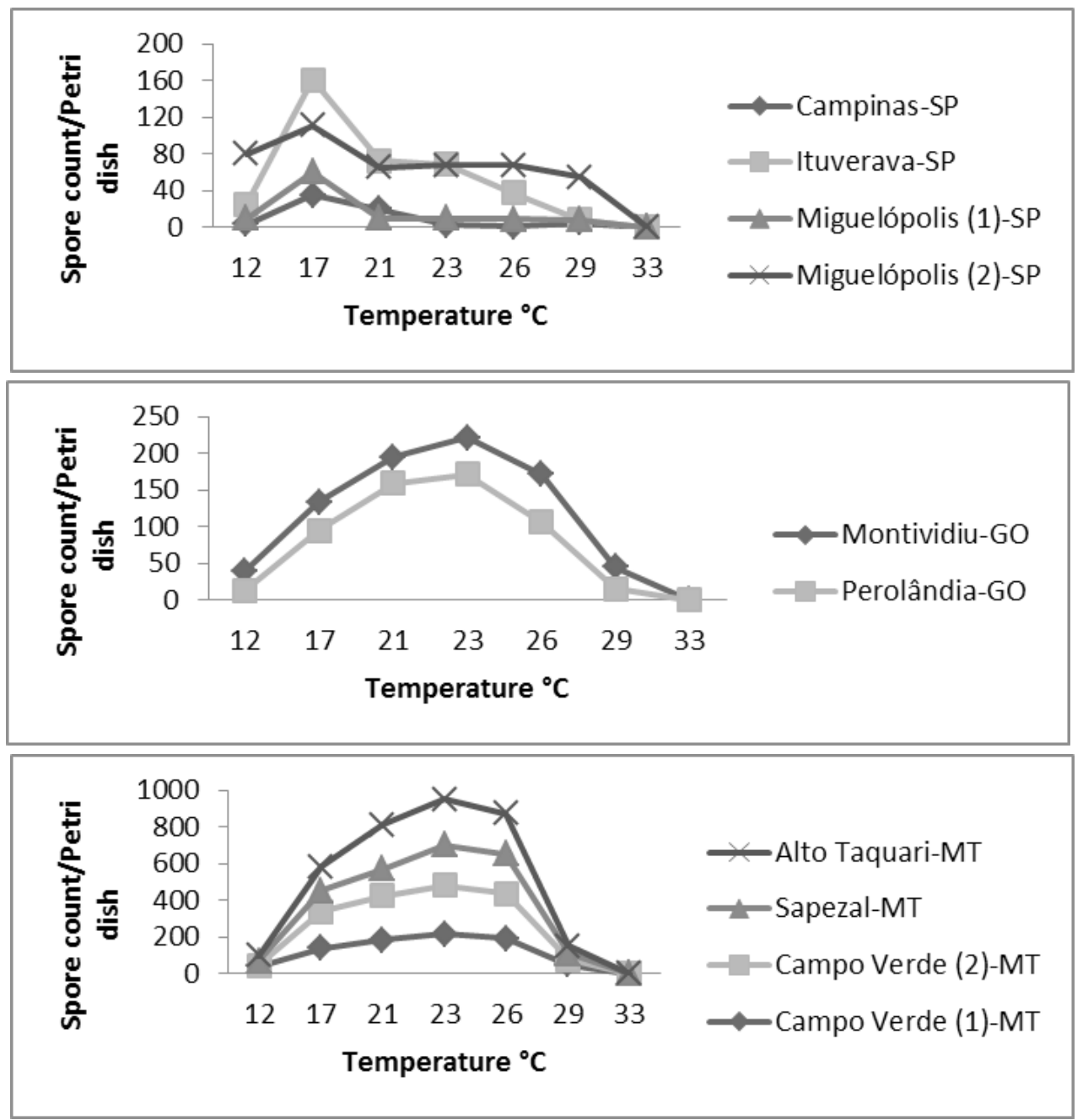

Figure 1. Mean spore count (x 100,000) per Petri dish (9 cm of diameter) for Ramularia areola isolates from different Brazilian States (SP, GO and MT) incubated at different temperatures. 
Table 1. Mean spore count (x 100,000) per cotton leaf for eight genotypes inoculated with Ramularia areola isolates originated from different Brazilian States*.

\begin{tabular}{|c|c|c|c|c|c|c|c|c|c|c|c|c|c|c|c|c|c|}
\hline \multirow{3}{*}{$\begin{array}{c}\text { R. areola } \\
\text { Isolates }\end{array}$} & \multirow{3}{*}{$\begin{array}{c}\text { States* } \\
\text { BA }\end{array}$} & \multicolumn{16}{|c|}{ Cultivars** } \\
\hline & & \multicolumn{2}{|c|}{1} & \multicolumn{2}{|c|}{2} & \multicolumn{2}{|c|}{3} & \multicolumn{2}{|c|}{4} & \multicolumn{2}{|c|}{5} & \multicolumn{2}{|c|}{6} & \multicolumn{2}{|c|}{7} & \multicolumn{2}{|c|}{8} \\
\hline & & 3 & $a b$ & 188 & $\mathrm{ab}$ & 197 & $\mathrm{a}$ & 1 & $\mathrm{a}$ & 5 & $\mathrm{a}$ & 17 & $\mathrm{a}$ & 0 & a & 46 & $\mathrm{a}$ \\
\hline 294 & MT & 1 & $\mathrm{~b}$ & 32 & bed & 28 & $a b$ & 4 & $\mathrm{a}$ & 2 & $\mathrm{a}$ & 10 & $\mathrm{a}$ & 12 & $\mathrm{a}$ & 0 & $\mathrm{a}$ \\
\hline 282 & MT & 0 & $\mathrm{~b}$ & 167 & $a b c$ & 20 & $\mathrm{~b}$ & 0 & $\mathrm{a}$ & 3 & $\mathrm{a}$ & 24 & $\mathrm{a}$ & 2 & $\mathrm{a}$ & 2 & $\mathrm{a}$ \\
\hline 283 & MT & 6 & $\mathrm{ab}$ & 269 & $\mathrm{a}$ & 172 & $\mathrm{a}$ & 4 & $\mathrm{a}$ & 2 & $\mathrm{a}$ & 45 & $\mathrm{a}$ & 3 & a & 4 & $\mathrm{a}$ \\
\hline 281 & MT & 2 & $\mathrm{~b}$ & 89 & $a b c$ & 18 & $\mathrm{~b}$ & 11 & $\mathrm{a}$ & 6 & $\mathrm{a}$ & 54 & $\mathrm{a}$ & 8 & $\mathrm{a}$ & 46 & a \\
\hline 300 & PR & 7 & $a b$ & 22 & $\mathrm{~cd}$ & 19 & $\mathrm{~b}$ & 15 & $\mathrm{a}$ & 3 & $\mathrm{a}$ & 4 & $\mathrm{a}$ & 11 & a & 2 & $\mathrm{a}$ \\
\hline 290 & SP & 31 & $a b$ & 9 & $\mathrm{~cd}$ & 19 & $\mathrm{~b}$ & 13 & $\mathrm{a}$ & 11 & $\mathrm{a}$ & 5 & $\mathrm{a}$ & 4 & $\mathrm{a}$ & 7 & $\mathrm{a}$ \\
\hline
\end{tabular}

*Brazilian States. **1: CNPA-GO-06-158; 2: DELTAOPAL; 3: FM 966 LL; 4: FMT 705; 5: FMT 707; 6: IAC 25RMD; 7: IMA 03-1318; 8: IMACD 05-8276. Letters in the columns refer to the comparison of isolates within genotypes using Tukey's test at $5 \%$ probability. Coefficient of variation $=35.4 \%$.

temperature at which maximum sporulation occurred varied with the origin of the isolates. The optimal temperature was approximately $17^{\circ} \mathrm{C}$ for isolates from the state of São Paulo and approximately $23^{\circ} \mathrm{C}$ for isolates from the states of Goiás and Mato Grosso. The average temperature during the cotton cultivation period differs considerably among different regions. Temperature may have been responsible for the spore production potential and, at the end of the plant cycle, for the disease severity and for the survival mechanism of the regional isolates.

The results of spore count per leaf shown in Table 1 indicate variability in the aggressiveness of isolates originated from different geographic regions. Most of the isolates showed aggressiveness on two highly susceptible cultivars, DELTAOPAL and FM966LL, which produced the largest quantity of spores. The other isolates yielded relatively smaller number of spores on the reaming six cultivars. These data evidence the aggressiveness of such isolates on the two cultivars grown in Brazil. Nonetheless, further studies on this subject are needed to understand the distribution frequency of such isolates in each Brazilian State, since the spore production period of a single lesion was not studied. Spores are produced during a very short period of time, causing rapid senescence and premature death of the leaves; thus, studies on the sporulation period of a single lesion or a single leaf would still be desirable.

The results found in this study show the possibility of optimizing Ramularia spot control in Brazil due to the sporulation potential of this fungus. On the one hand, susceptible cultivars of high sporulation capacity should be avoided in order to keep the disease at low levels. On the other hand, fungicide applications to restrain fungal sporulation will be more efficient at temperatures around $17^{\circ} \mathrm{C}$ for São Paulo State and $23{ }^{\circ} \mathrm{C}$ for Mato Grosso and Goiás States. Such a strategy is believed to contribute to a more efficient disease control, as well asto a better and more rational fungicide use, since the 5-9 applications presently carried out for the pathogen control may be unsustainable.

\section{REFERENCES}

1. Andrade Junior, E.R.; Galbieri, R.; Eficiência de fungicidas no controle de mancha de ramulária em algodoeiro, na safra 2013/14 no Mato Grosso. Circular técnica nº12/IMA, Cuiabá, 8 p., 2014.

2. Aquino, L.A.; Berger, P.G.; Rodrigues, F.A.; Zambolim, L.; Ogoshi, F.; Miranda, L.M.; Lélis, M.M. Controle alternativo de mancha de Ramularia do algodoeiro. Summa Phytopathologica, Botucatu, v. 34, n. 2, p. 131136, 2009.

3. Cia, E.; Fuzatto, M.G.; Kondo, J.I.; Ohl, G.A.; Galbieri, R. Reação de genótipos de algodoeiro à mancha de Ramularia em diferentes épocas e ambientes. Summa Phytopathologica, Botucatu, v. 39, n. 3, p. 193-197, 2013.

4. Novaes, T.G.; Almeira, W.P.; Schuster, I.; Aguiar, P.; Mehta, Y.R. Herança de resistência do algodoeiro a Ramularia areola. Summa Phytopathologica, Botucatu,v. 37, pp. 150-152, 2011.

5. Pizzato J.A.; Araújo, D.V.; Galvanin, E.A.S.; Romano Júnior, J.; Matos, A.N.A.; Vecchi, M.; Zavislak, F.D. Geostatistics as a methodology for studying the spatiotemporal dynamics of Ramularia areola in cotton crops. American Journal of Plant Sciences, Irvine, v. 5, p.2472-2479, 2014.

6. Pizzato, J.A.; Araújo, D. V.; Serafim, M.E.; Araújo, K.L.; Dallacort, R.; Gílio, A. S.; Romano Jr., J.; Maciel, V.A. Epidemiologic study of Ramularia areola under different soil covers and spacings, for cotton crops. American Journal of Plant Sciences,Irvine, v. 4, p.2049-2059, 2013.

7. Rathaiah, Y. Reaction of cotton species and cultivars to four isolates of Ramularia areola. Phytopathology, Saint Paul, v. 66,p. 1007-1009, 1976.

8. Shivankar, S. K.; Wangikar, P. D. Estimation of crop losses due to grey mildew disease of cotton caused by Ramularia areola. Indian Phytopathology,New Delhi, v. 45, n. 1, p. 74-76, 1992. 